\title{
A Tale of Two Governments? Government Responses and Perceived Influence in the 2014 Protests in Bosnia and Herzegovina
}

\author{
Margherita Belgioioso \\ University of Essex \\ Kristian Skrede Gleditsch \\ University of Essex \& Peace Research Institute Oslo \\ Dragana Vidovic \\ University of Essex
}

-We are grateful to comments from Kristin Bakke, Daniel Berger, Cullen Hendrix, and all the participants at the workshop on "Urban Insecurity and Civil Conflict" at Oxford University, 22-23 November 2015. The authors are listed in alphabetical order, equal authorship implied. Gleditsch acknowledges the support of the European Research Council (313373) and the Research Council of Norway (213535/F10). Contact information: \{Margherita Belgioioso | Kristian Skrede Gleditsch | Dragana Vidovic\}, Department of Government, University of Essex, Wivenhoe Park CO4 3SQ, emails: \{mbelgia@essex.ac.uk|ksg@essex.ac.uk|dvidov@essex.ac.uk\}. 


\begin{abstract}
Bosnia and Herzegovina $(\mathrm{BiH})$ experienced an unprecedented wave of non-sectarian anti-government protests in 2014. Although the key motivating factors generally highlighted such as economic marginalization and poor governance were common throughout Bosnia and Herzegovina, the protests did not extend to all parts of the country. Notably, despite very similar initial conditions in the two jurisdictions of the country, the Federation of Bosnia and Herzegovina (FBiH) saw major unrest with a large number of participants in many locations while subsequent protest mobilization was much more limited in the Republic of Srpska (RS). We take advantage of the variation in the responses from the two governments in the same country to evaluate how observed and anticipated government responses can shape the willingness to join dissident activity. We argue that variation in government responses and its impact on perceptions on prospects for successful collective action can help account for the differences in mobilization across the two entities. We test our expectations using a new data set on protest events, participants and government responses in $\mathrm{BiH}$ from January to April 2014. Our findings are consistent with the argument that coherent repressive government policies tend to suppress mobilization, while mixes of repressive responses and concessions from the government can encourage further mobilization. The results for $\mathrm{FBiH}$ show clear variation in protest following changes in government behavior, and are consistent the claim that repressive responses likely suppressed mobilization in the RS.
\end{abstract}




\section{Introduction}

In early 2014, Bosnia and Herzegovina experienced a period of extensive large-scale anti-government protest following initial demonstrations and riots in the town of Tuzla on 5 February (Sadiković 2014: 71). The 2014 protests in Bosnia and Herzegovina were unusual in that mobilization focused on dissatisfaction over the widespread economic marginalization and generally poor governance in the country rather than the cleavages between the three main ethnic groups - i.e., Bosniaks, Croats and Serbs. As such, the largely non-sectarian 2014 protests presented a clear departure from the dominant ethnic narrative that has been seen as characteristic of the country since the prior civil war (see Beber 2006, 2014).

Bosnia and Herzegovina has a unique political structure with two largely autonomous governing units, namely the Federation of Bosnia and Herzegovina $(\mathrm{FBiH})$ and the Republic of Srpska (RS). As we will show in more detail later, similar initial social and economic conditions in the two units provide a clear common motivation for grievances against the government in both jurisdictions. Yet, only in the $\mathrm{FBiH}$ did the initial 2014 protest escalate into major mobilization, while the RS did not see the same degree of mass unrest. We argue that role of observed and anticipated government responses in shaping individual perceptions of the prospects for successful collective action and hence their willingness to join in dissent can account for the differences in mobilization across the two entities. In particular, we argue that an inconsistent mix of accommodative and repressive responses in $\mathrm{FBiH}$ increased individual expectations about the efficacy of protests and hence their willingness to participate in dissent, while the consistent repressive responses in RS quashed hopes for concessions to protest and undermined individual participation and growth in mobilization. 
Out propositions build on an extensive body of prior theoretical and empirical interest research on how differences in government responses affect mobilization (see, e.g., Cunningham and Beaulieu 2010; Klandermans 1984; Lichbach 1987; Rasler 1996). However, the unique dual government structure in Bosnia and Herzegovina provides an exceptional case to directly examine the impact of differences in government responses for participation and expectations. The widespread, social and economic problems faced by the population at large are similar throughout the country. The unusual political and administrative division between the two parts of Bosnia and Herzegovina provides us with two distinct yet comparable cases with partly independent government responses. This allows us to observe how different observed and expected government responses can affect popular mobilization, while holding constant plausible grievances and initial conditions.

Our study uses a new event dataset that we have collected on the protest in Bosnia and Herzegovina over the period January-April 2014, using local news media sources. These have much greater coverage than what would be available if we relied only on information taken from English language media reports. Our event data also record government responses to individual events and allow us evaluate systematically our propositions on how government repression and accommodation will affect subsequent mobilization or level of contentious collective action. Unlike other time-series analysis of individual countries we can consider actual variation in government responses across two different jurisdictions within the same country, thus plausibly holding a number of other simultaneous and contextual factors constant when making comparisons. To anticipate our findings, the results from our empirical analysis are consistent with the argument that the use of consistent repressive policies in the RS likely suppressed contentious activity and mobilization, while an 
inconsistent mix of repressive and accommodative policies in the $\mathrm{FBiH}$ encouraged contentious activity and mobilization.

We first provide a brief overview of the 2014 protests in Bosnia and Herzegovina, and the historical background and motivation for the protests. We then highlight the divergent patterns of mobilization, contrasting the escalating massmobilization in the FiBH with the lack of major mobilization in RS. We show more formally how the salience of grievances per se does not provide a plausible explanation for the divergent patterns. We argue that differences in the responses by the different governments and their effects on individual mobilization provide a more plausible explanation for the divergent events, supported by our new data and qualitative evidence.

\section{Grievances and opportunities in post-Dayton Bosnia and Herzegovina}

The 1995 Dayton Peace Agreement (DPA) aimed to establish peace and democratic rule in Bosnia and Herzegovina. Although the DPA clearly succeeded in ending the devastating civil war the country and preventing a recurrence of armed violence, neither of the two semi-independent entities in Bosnia and Herzegovina that resulted from the agreement - i.e., the $\mathrm{FBiH}$ and the $\mathrm{RS}$ - have seen much progress in either sustained economic reconstruction or developing effective governance. The unfinished transition to a fully functional independent and democratic state after the DPA has left individual citizens in contemporary Bosnia and Herzegovina with very little space to play a meaningful active role in politics, beyond casting votes at regular elections. After the initial social and economic devastation of the civil war in the 1990s, citizens in Bosnia and Herzegovina have continued to endure widespread poverty, severe unemployment, political ineffectiveness and very high levels of 
corruption over the last two decades (see Beber 2006; Mujanovic and McRobie 2014; Pugh 2005).

The 2014 protests were very much rooted in political and economic grievances rather than the ethnic cleavages that often have been seen as dominating politics in Bosnia and Herzegovina. The most proximate triggering events arose over a breakdown in labor relations, which in turn was a consequence of the privatization of the former state-owned factories which left many workers throughout Bosnia and Herzegovina unemployed, stripped of assets, in debt, and without access to health care or key social benefits (Šunj 2014). More specifically, workers at the Dita detergent factory in the northern city of Tuzla in the FBiH had threatened the government with the strike action since 2009. They initiated their first actual strike in August 2011 over claims that the company owed its employees 7 months of unpaid salaries as well as 22 months of pension and health insurance payments (Busuladžić 2014: 15). After the first strike, workers at the Dita factory were joined by employees of other former state-owned companies such as the Konjuh furniture factory in the nearby town of Živinice, as well as the Guming motor firm and the Poliohem chemical plant in Tuzla (Arsenijević 2014). Beyond the grievances by workers against these specific firms, the protests were also directed against the government and the highly non-transparent privatization policies that had led to job losses and layoffs, as well as the fact that some of the companies were seen as been given favorable treatment and been allowed to declare bankruptcy (Radio Sarajevo 2014). All the key political institutions in $\mathrm{BiH}$ largely ignored the plight of the workers throughout 2013. This reflected in part the common perception that there was little threat of protest escalation, even if the broader grievances and views expressed by the workers might be widely shared by other segments of the population. 
However, on 5 February 2014 the workers' movement in Tuzla successfully managed to mobilize over 1000 people to demonstrate in front of the local cantonal government. This largely nonviolent march on the local authority headquarters in Tuzla was followed by thousands of protesters in the streets of 24 towns and cities across the country over the next couple of days, including the capital Sarajevo as well as major cities such as Banja Luka, Brcko, Jajce, Mostar, and Zenica, (Cihan News Agency 2014; Dnevni Avaz 2014; Haber 2014; Marzal 2014; Milan 2014). Although there were some minor and isolated violent acts by the protesters, the mobilization in the $\mathrm{BiH}$ against the government was largely non-violent. Moreover, there was increasing evidence of dissident organization and coordination as the events unfolded (De Noni 2014). After some government buildings were set on fire in early February 2014, many protesters turned out to clear debris to show that they were prepared to "clean up this mess, like we'll clean up the politicians who made this happen". Furthermore, it was clear that the protest enjoyed widespread support. A poll carried out by the news portal Klix (2014) on 12 February 2014, one week after the first events in the mass mobilization, showed very high support for the anti-government protest among a majority of the population through Bosnia and Herzegovina.

However, the subsequent escalation in popular mobilization in the FBiH did not extend to the RS. Despite some early minor protests in the RS capital city of Banka Luka, the incipient popular uprising in RS remained at a very low level of mobilization throughout the entire period of the 2014 protests (Arsenijević 2014). This is at first a surprising outcome, since the basis for the grievances and opportunities for mobilization would seem very similar across the two jurisdictions.

\footnotetext{
${ }^{1}$ See http://uk.reuters.com/article/uk-bosnia-unrest-idUKBREA160VJ20140208.
} 
Many perspectives on mobilization highlight the material basis of grievances, and how this can give rise to alienation and frustration that in turn motivates individual action and support the growth of broader social movements (see, e.g., Gurr 1970; Kerpelman 1969; LeBon 1896; Landsberger 1976). However, although existing economic data and estimates suggest pervasive marginalization in Bosnia and Herzegovina, they provide little basis for clearly worse conditions or likely grievances being notably stronger in the FBiH than the RS. According to the Labor Force Survey's (2014) official statistics we see very high unemployment rates in both of the units, i.e., $28.4 \%$ in the $\mathrm{FBiH}$ and $25.7 \%$ in the RS. Although the rate in $\mathrm{FBiH}$ is marginally higher, unemployment rates in excess of $25 \%$ are very high in absolute terms by comparison to other countries in Europe, and even above the unemployment rate for Greece typically considered extreme. An effort to derive a composite index of social exclusion, based on the risk of poverty, financial depravation, and employment security estimates, suggests that half of the $\mathrm{BiH}$ population is socially marginalized, with an estimated percentage excluded population at $52.6 \%$ for RS and $45.6 \%$ in the FBiH (Ceriani and Laderchi 2015: 16). By this measure, the levels of social exclusion seem high in absolute terms across the two units, and if anything higher in RS than FBiH. Moreover, the high social exclusion is long-standing, and there is also no evidence suggesting dramatic social or economic changes immediately prior to 2014 in the $\mathrm{FBiH}$ relative to the $\mathrm{RS}$.

With regards to more political grievances, most observers agree that similar clientelistic rule with ineffective and corrupt bureaucracies have been prevalent and had similar effects across the two different jurisdictions in of the country. There is also no clear ethnic bias in political and economic marginalization, which affects in individuals in the Bosniak, Croat, and Serb communities alike. The common 
motivations and efforts to mobilize all ethnic groups across the ethnic divides that had dominated in Bosnia and Herzegovina since the civil war were explicitly highlighted by the protesters themselves. In fact, the protesters used the chant "we are hungry in all three official state languages" to demonstrate the common and cross-ethnic bases of their grievances (E.S. 2014; International Crisis Group 2014).

Beyond the similarities in plausible motivation, there are also no obvious differences in factors affecting opportunities for mobilization between the two units that can explain the divergent outcomes. For example, it is commonly argued that collective action is more difficult across ethnic groups and that the barriers to nonsectarian mobilization thus should be higher in ethnically divided societies, with mistrust across ethnic groups (see Alesina and La Ferrara 2002, 2003). However, this would imply that mobilization should be easier in the more ethnically homogenous RS than the more heterogeneous $\mathrm{FBiH}$, where the protest grew the most. Moreover, there are no obvious differences when it comes to the structure and the influence of the pre-existing formal political organizations, such as labor unions or nongovernmental organizations, or informal social networks that may facilitate collective between the two jurisdictions (see Fischer 2006).

Given these general similarities in the initial conditions and the cross-ethnic composition of the protesters, it is difficult to see how variation in structural conditions and grievances specific to individual ethnic groups can suffice to explain the different trajectories we observe in the evolution of the protests across the two semi-independent entities in Bosnia and Herzegovina. Instead, we turn to the different government and opposition conflict dynamics unfolding in the $\mathrm{FBiH}$ and in $\mathrm{RS}$ during the initial months of the 2014 uprising. Drawing on prior research by Cunningham and Beaulieu (2010), Klandermans (1984), Lichbach (1987) and Rasler (1996), we 
posit that the differences in government responses and how these affect peoples' perceptions of the prospects for successful collective action and the likelihood that others will participate can account for the differences in observed mobilization patterns in the $\mathrm{FBiH}$ and $\mathrm{RS}$. In particular, accommodating government responses that increase expectations about the efficacy of mass mobilization will affect the willingness of others to join ongoing dissent once we see initial mobilization. By contrast, repressive responses are likely to reinforce beliefs that dissent is unlikely to be effective and undermine individual willingness to participate. As such, government responses to dissent and protest play a crucial role in either increasing or decreasing subsequent mobilization, depending on how individual protest is met, or how protesters expect the government to respond to dissent. We argue that the consistent repressive government responses in the RS undermined any hope for success or more general optimistic expectations about the ability to obtain political demands through protests. By contrast, the mix of repressive and accommodative responses seen for the FBiH government helped increase the willingness of individuals to participate in protest as they became persuaded that protest could be effective, in the sense of helping to promote their political goals and that their participation could encourage other individuals to participate.

\section{Grievances, collective action, and mobilization in dissent}

Olson (1965) popularized the collective action problem, or how common interests by themselves do not suffice to generate collective mobilization if undermined by individual incentives. In dissent, the costs of participation are borne by each individual and potentially very high, while any benefits to action are collective and non-excludable to non-participants. As such, common grievances and the potential 
benefits from successful efforts are not sufficient to elicit individual participation in collective mobilization, and individuals will generally have incentives to free-ride on the contributions of others rather than participate in dissent.

There is an extensive body of research that examines how the collective action problem can be overcome and what may convince people to participate in dissent, despite the lack of clear individual incentives (see, in particular, Lichbach 1995). Perhaps most prominent is the resource mobilization school, which argues that various structural factors facilitate mobilization. This includes political factors such as a more liberal political regime that constitute a more permissive environment, social and economic resources for mobilization such as higher human capital and individual skills, or more developed social capital including pre-existing organizations or better established networks that help make it easier to coordinate large scale contentious collective action (see, e.g., Andrews and Biggs 2006; Gamson 1975; Gamson et al. 1992; Marx and Wood 1975; McCarthy and Zald 1977; Oberschall 1973; Snow et al. 1980; Zald and McCarthy 1979). But as discussed above for motivation, the similar initial social and economic conditions implies that resources per does not provide leverage to explain why initial low-level mobilization turned into a major protest campaigns against government in the $\mathrm{FBiH}$ whereas major mobilization did not follow after the initial protests in RS.

A more promising alternative lies in how the interaction between dissidents and the authorities shape the subsequent growth or quelling of incipient political mobilization. Social movement research generally argues that extra-institutional contentious collective action grows as a result of the interactions between non-state actors and the state. According to Tilly and Tarrow (2007: 92), for example, "in most of such (major protest) cycles, contention begins moderately and in interaction with 
institutions". Extra-institutional protests aims to produce political change and actors are particularly likely to resort to direct action methods when they believe that changes cannot be obtained through regular institutional political channels or conventional politics. Irregular political dissent typically arises from small, local networks of people that know each other. However, the growth of contentious collective action from initial mobilization often arises through more encompassing social networks with a sufficient of loosely connected individuals and organizations, i.e., the strength of weak ties phenomenon (Granovetter 1978; McAdam 2003; Tarrow 1994; Tilly and Tarrow 2007). Following specific interactions among mobilized social actors and the authorities, we may see an "upward scale shift" across space and sectors of the society, ultimately leading to much higher mobilization and more intense and geographically diffused contentious activity (see Tarrow 1994; Tilly and Tarrow 2007). ${ }^{2}$

Whether we get an upward scale shift or not ultimately depends on the extent of individual participation in a collective action, which again raises the collective action problem of net collective gains versus individual rationality (see Oberschall 1973). In general, individuals will normally be reluctant to contribute alone unless they have private incentives, or alternatively, something changes expectations that your own decision to participate is likely to affect others. Klandermans (1984) points

${ }^{2}$ Tilly and Tarrow (2007:95) argue that "[u]pward scale shift is one of the most significant processes in contentious politics. It moves contention beyond its local origins, touches on the interest and values of new actors, involves a shift of venue to sites where contention may be more or less successful, and can threaten other actors or entire regimes". 
to how expectations about the ability to change existing social and political conditions through protests shape individual willingness to participate following initial events. Thus, government responses to initial protest can thus further reinforce or actually change individual expectations about the effectiveness of contentious action based on your beliefs that your participation will make a difference and help foster mobilization.

Much of the existing literature on the evolution of mobilization has focused on repressive responses. There is a clear consensus that dissent perceived to constitute a threat is likely to generate repressive state responses, but much less agreement over the consequences of repression for dissent or mobilization (see Davenport 2007). As summarized by Rasler $(1996,133)$, existing research finds that “... repression has both positive and negative effects on government opposition". Some argue that government repression increases subsequent dissident through perceptions of injustice and outrage (e.g., Chenoweth and Stephan 2008, 2011; Francisco 1995; Kocher et al. 2011; Piazza and Walsh 2010), while others find that repression tends to successfully deter and decrease dissent and impede the ability of the opposition to mobilize (see Downes 2008; Jenkins and Perrow 1977; Oberschall 1973; Tilly 1978). Some scholars have argued for more complex non-liner relationships, for example that large-scale repression deters future dissent while lower level repression may fuel grievances and mobilization (e.g., Khawaja 1993, Muller and Weede 1990; Olivier 1991).

One limitation in many studies of repression is the lack of attention to other possible government response and how these affect mobilization. Accommodation is typically treated implicitly, as one of several alternatives that may happen in the absence of repression. Cederman, Gleditsch, and Wucherpfenning (2017) find 
evidence that reforms by government reduce the likelihood of ethnic violent conflict or promote conflict termination, but many concessions fall short of what dissidents seek and can also potentially encourage beliefs that greater concessions can be won through further mobilization in active conflict (e.g., Cederman et al. 2015). ${ }^{3}$ In some cases, accommodation may be selective, to specific demands, and reflect efforts by governments to divide movements (see Cunningham 2011). In other cases, governments simultaneously combine repressive and accommodative policies as a response to unrest in general or to particular tactics (see, e.g., Cunningham and Beaulieu 2010; Lichbach 1987: 267). Government repression and accommodation/concessions are not mutually exclusive responses, and the government is not always unified around a clear response or speak with one voice (Lichbach 1987). At the extreme, inconsistent responses can both raise expectations of concessions or efficacy through protest while increasing grievances over repression. Thus, the contradictory findings in existing research on the relationships between government responses and mobilization arises from not considering the full range of government responses.

Few existing studies take into account the role of contradictory government responses, where we see both repression and concessions by government, how this affects the subsequent evolution of dissent. One important exception is Rasler (1996), who analyzes government repression and concessions and protest escalation in the Iranian revolution. The limited availability of detailed or disaggregated protest event data has prevent broader comparative empirical studies, and most studies have been

${ }^{3}$ Of course, concessions may also be a result of prior dissent or accommodation (see Cedermant et al. 2015; Thomas 2014). 
forced to rely on aggregated annual counts, without detailed information on the responses of governments to specific individual events. By contrast, our study offers a new dataset of the protest in Bosnia and Herzegovina with daily coding of protests events and government responses. These allow us to consider the number of participants in events as a measure of mobilization intensity at a much more disaggregated level and introduce variation in government responses across two different jurisdictions within the same country, thus plausibly holding a number of other potential factors constant when making comparisons, given the overall strong structural similarities across different regions in the country. We expand below on our propositions on how differences government responses can shape subsequent mobilization and explain the divergent patterns in the two jurisdictions in Bosnia and Herzegovina.

\section{Explaining the divergent mobilization in FBiH and RS}

In line with Klandermans' (1984) expectancy-value theory, we argue that government responses to initial protest shape individual expectations about the ability and effectiveness of foster social and political change through protests and thus their willingness to participate. The grievances that motivated the protests were widely shared throughout Bosnia and Herzegovina. However, the subsequent government responses influenced people's views on whether protests would be effective or not, thus shaping individual willingness to participate. We first substantiate the common appeal of the protest, before turning to factors affecting perceptions of efficacy and individual willingness to participate.

Beyond the material basis for widespread grievances in terms of severe social, economic and political motives such as poverty, corruption and unemployment 
present throughout all of Bosnia and Herzegovina, the widespread appeal of the protest is borne out by opinion survey. The Klix (2014) survey mentioned above indicated that a clear majority supported the protest in both entities, with $93 \%$ of respondents in $\mathrm{FBiH}$ expressing support and $78 \%$ in favor in the RS. The appeal of the protest was also bolstered by their largely non-violent nature. Although the initial protest events by workers in former-state owned companies included some displays of disorder such as a series of buildings set on fire, the movement generally managed to contain violence and prevent further escalation of isolated lower-level violence. This is important for a number of reasons. First, it has been showed that nonviolent direct action has generally lower barriers to increasing participation, as it does not require specific skills of or extensive training, and does not require overcoming moral barriers as resort to the use of violence often entails. As such, nonviolent dissent can in principle attract a much larger number of participants and more quickly than violent dissent (see Chenoweth and Stephan, 2011; Dahl et al 2016). Second, violence can often crowd out participation. Indeed, more than half of the respondents in the Klix (2014) survey said that they would stop supporting the anti-government protests in the event that violence were to become widespread. ${ }^{4}$

\footnotetext{
${ }^{4}$ Some prior research has conceived of government consistency in terms of responses to particular tactics and how this affects tactic choice by dissidents, e.g., violent or non-violent strategies (see Cunningham and Beaulieu 2010). This is interesting in its own right, but in our view less relevant to the $2014 \mathrm{BiH}$ protests, where there was no organized violence and resort to large-scaled organized violence would not have been feasible over the relatively short period. Thus the main strategic issue for the dissident movement was to control incidental violence or fighting with security forces.
} 
There is also evidence of both accommodation and repression to the antigovernment protest wave. In the $\mathrm{FBiH}$ we observe both of these at the same time, as the government on the one hand expressed a great deal of sympathy with the motives of the protests, while at the same time condemned the disruptive effects of the protest and calling for the protest activities to cease "for the good of the country". For example, when over 10000 people took to the streets in Tuzla, Sarajevo and other key towns in FBiH on 7 February 2014, 4 Cantonal prime ministers and 43 government officials of the FBiH resigned (Sladojević and Lingo-Demirović 2014). We believe that this highlighted to the protesters the possible efficacy of nonviolent protest against political elites and encouraged further mobilization. At the same time, the government also engaged in acts of repression, as they sought to ban protest activities and threatened severe sanctions against individuals taking parts in protests, including 5 year prison sentences for terrorism (see Sladojević and Lingo-Demirović 2014).

We posit that the key element for understanding the different mobilizations trajectories in the $\mathrm{FBiH}$ and in RS over the January-April 2014 period stem from divergent government responses and how these shaped expectations about the efficacy of protest to obtain desired political outcomes and the prospects for largescale mobilization. Irrespective of how valuable a collective good is, individuals will have little incentive to participate if they do not expect participation to be successful or that their individual participation will have some influence. Thus, government responses can shape mobilization in positive and negative ways. Although individuals do not precisely know what will happen, they develop expectations about their ability to obtain desired policy outcomes throughout dissident activities based on how the state reacts to contentious political behavior. 
The 2014 protest wave originated in the common economic quagmire of postwar $\mathrm{BiH}$, but the initial events in $\mathrm{FBiH}$ changed expectations about the prospects for success. The workers at a pharmaceutical plant in Tuzla who filed lawsuits in 2011 after not receiving salaries or access to health care for months managed to enlist the support and participation of other workers in former state owned companies, and the legal struggle evolved into coordinated nonviolent protests and occupations. Until the beginning of 2014 , however, the courts did not rule on any of the lawsuits, and the Tuzla Cantonal court strongly condemned workers for engaging in unlawful acts of civil disobedience actions such as street blockage (Bhprotestfiles 2014). In January 2014, when the national courts finally ruled in favor of their lawsuit, there was a legitimizing push to the workers' demands and the subsequent protest activities. ${ }^{5}$

This concession, we argue, led the potential mobilizers to update their beliefs and expectations on the efficacy of extra-institutional contentious for political and social change and increase their willingness to participate. From 5 to 8 February 2014, the numbers of protesters increased by thousands, and the demonstrations spread to many of the main cities of the FBiH and RS, including Sarajevo, Zenica, Mostar and Bihac, Banja Luka, Prijedor. ${ }^{6}$ In the $\mathrm{FBiH}$, the police met protesters with increasing violence, and dissent became increasingly confrontational, including storming and setting fire to government buildings. The protests lead to the resignation of many local authorities. Leading political figures lent support for the legitimacy of the campaign, including the President of the FBiH Živko Budimir, who said that "social

\footnotetext{
${ }^{5}$ See documentary at https://www.youtube.com/watch?v=_NwDIW3wBDY.

${ }^{6}$ https://www.youtube.com/watch?v=LjLiFhtR8t0 ; DefenceWeb, 10 February 2014.

Bosnia rocked by spreading anti-government unrest.
} 
uprising in the $\mathrm{BiH}$ has been on the horizon for years, it was only a matter of time before it would escalate" (DL.O. 2014). However, these statements stood in stark contrast to the repressive reactions of the police forces on the ground (DL.O. 2014).

We believe that inconsistent responses in $\mathrm{FBiH}$, mixing repressive and accommodative behaviors, helped highlight enduring grievances and encourage further non-violent mobilization, and also indicated the possible efficacy of protest to citizens and social networks in FBiH. By contrast, the initial mobilization in RS was met exclusively with repression by government officials, including threats of imprisonment, fines, and efforts to discredit the protests. The President of the RS, Milorad Dodik, actively sought to discredit protesters by calling them traitors and rabble-rousers, and argued that the primary aim of protesters was the destruction of the RS (Jukić 2014). Furthermore, President Dodik even dared to challenge the criticisms of the government voiced by former soldiers in the RS, a group which had been previously generally supportive of the RS institutions since the end of the civil war (Jukić 2014). These consistently repressive government reactions likely lowered the perceptions of individuals in the RS that protest could be effective, and thus ultimately undermined individual willingness to participate in the wake of the initial events.

Figure 1 below summarizes out argument that that FBiH government's inconsistent repressive and accommodative behavior increased the value of collective dissent through individual expectations about the ability to generate social and political change through contentious collective action and a higher willingness to participate. By contrast, the RS government's consistent repressive behaviors decreased the expected efficacy of protest activities, thereby decreasing the individual willingness to participate in the anti-government campaign and undermining the 
growth of extra-institutional contention activities. As we do not observe the same government response inconsistency in $\mathrm{RS}$ as in the $\mathrm{FBiH}$, we never reach the subsequent stage in the flow diagram.

\section{Figure 1: Government Inconsistency and Mobilization}

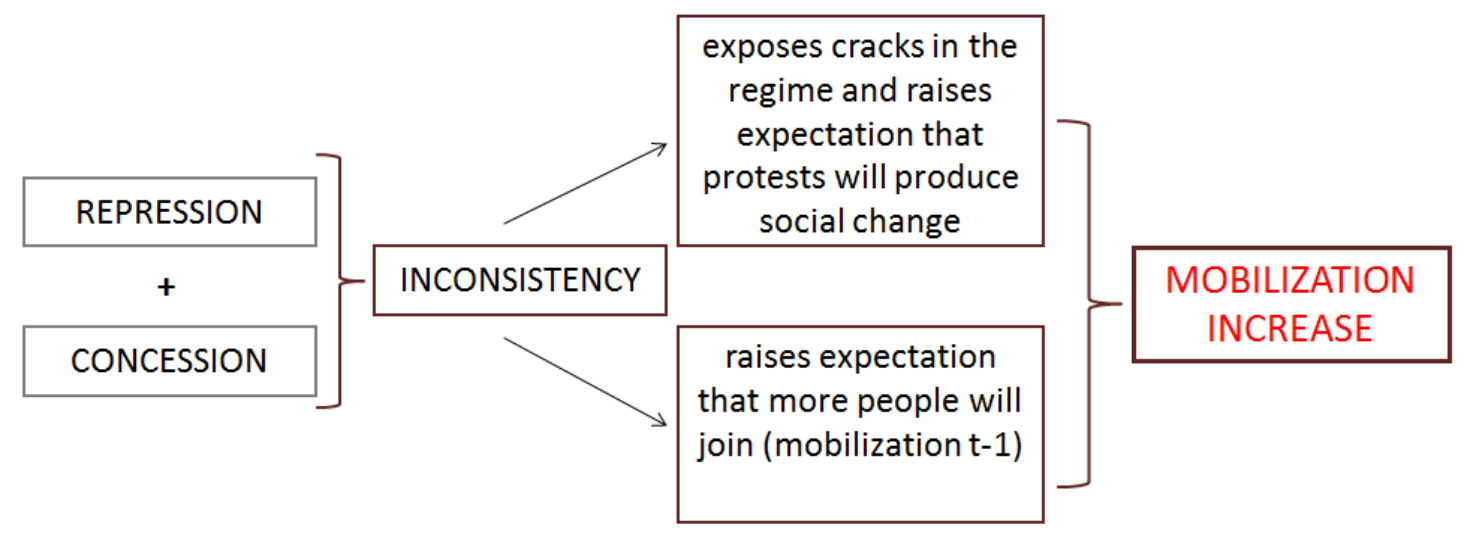

In the following section, we present new data on participation in primarily non-violent contentious collective activities in $\mathrm{BiH}$ in 2014 and then use these data to test our argument.

\section{Data on the 2014 protests and government responses}

We have collected daily protest event data on the 2014 protests in $\mathrm{BiH}$, drawing on two databases of daily news reports, one based on English language sources and another based on local sources. The local reports on the incidents in $\mathrm{BiH}$ far outnumber the coverage in English language sources, and they thus provide for a much more detailed database than just relying on foreign media sources. We have used the LexisNexis database to extract news items from English-language sources, 
including among others The Guardian, Agence Presse France, BBC, and Reuters. ${ }^{7}$ We have used the INFOBIRO database to extract local daily news reports from digitized local sources including Nezavisne, Oslobodjenje, Dnevni Avaz, Danevni List. $^{8}$ Moreover, the local sources are diverse both in terms of orientation and geographic origins. In the $\mathrm{FBiH}$, Oslobodjenje and Dnevni Avaz are based in the $\mathrm{BiH}$ capital of Sarajevo and Dnevni List is based in Mostar, while Nezavisne Novine is based in Banjaluka, the capital of the RS entity. Appendix 1 provides a complete list with the number of items extracted by the individual sources. The audience and the monthly newspaper circulation differ. Oslobodjenje and Dnevni Avaz are mainly read by Bosniaks in the FBiH, Dnevni List by Croats and Bosniaks in FBiH and Nezavisne Novine by the Serb population in the RS.

We used a search string of key words intended to capture protest related articles from the electronic sources. The full set of the keywords used are listed in Appendix 1. Based on these we first retrieved all potentially relevant articles for the period 1 January 2014 to 30 April 2014, and then apply manual inspection and the more detailed classification scheme. The majority of the protest events and government responses occurred in the month of February, and our data thus covers the entire cycle of the 2014 protest. We focus our analyses on the effects of government responses to that period. Figure 2 displays the recorded daily events by canton to illustrate the variation across the country. Figure 3 displays the recorded number or protesting individuals by canton. Finally, Figure 4 displays the $\mathrm{BiH}$

\footnotetext{
${ }^{7}$ See http://www.lexisnexis.com.

${ }^{8}$ See http://www.infobiro.ba/.
} 
territorial and administrative structure with the location of the cantons of the $\mathrm{FBiH}$ and the RS.
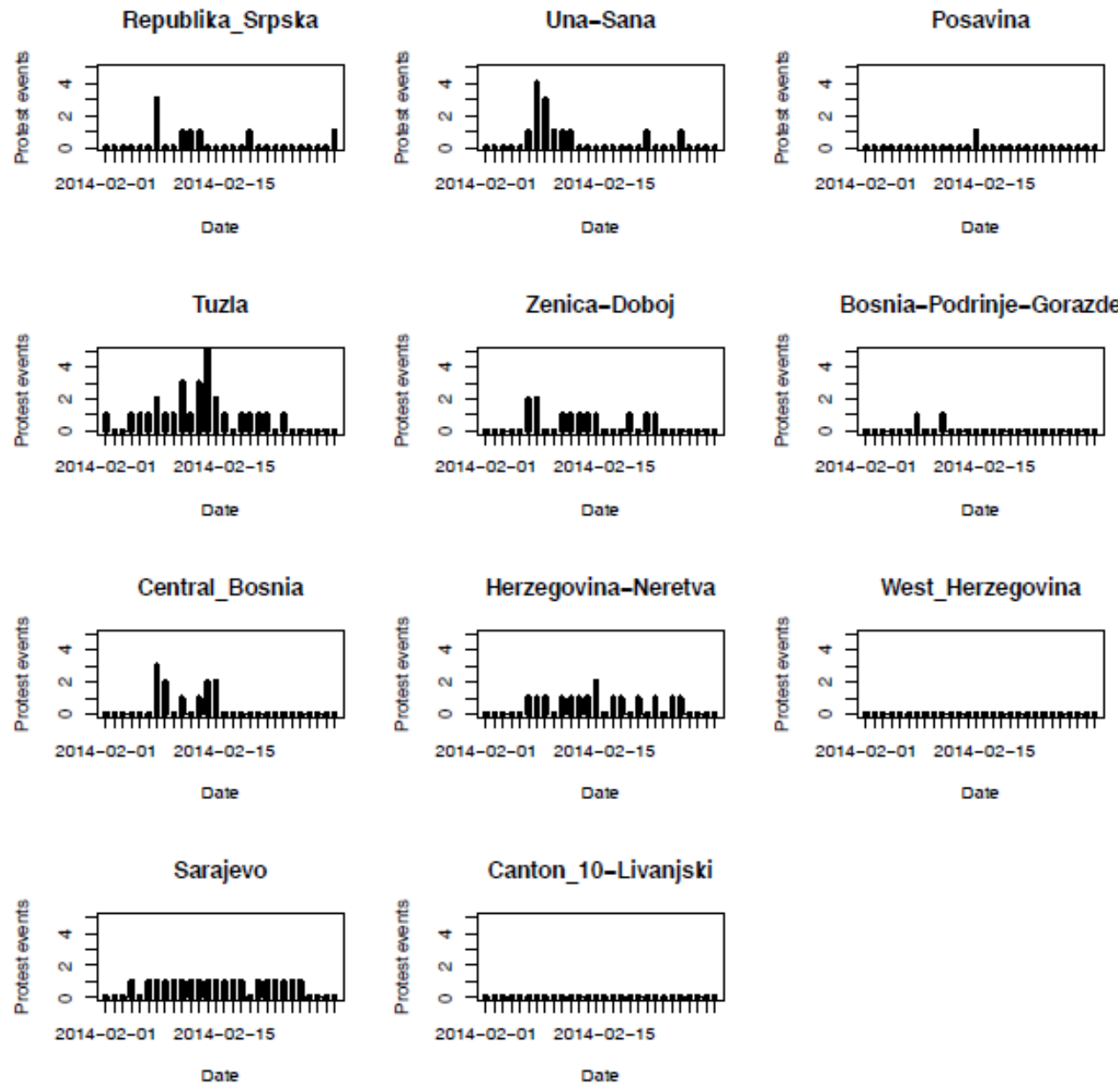

Figure 2: Daily protest events by FBIH canton and the RS. 


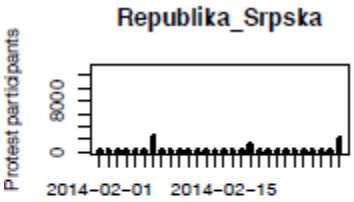

Date

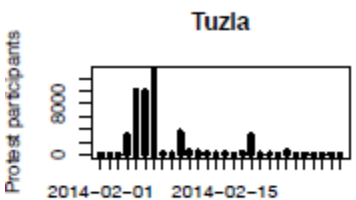

Date

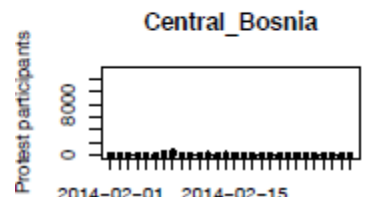

Date

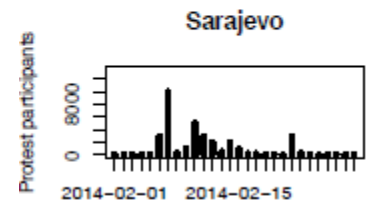

Date

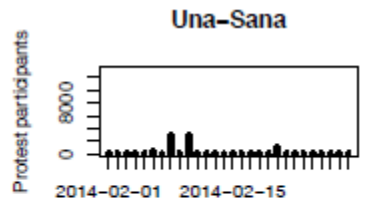

Date

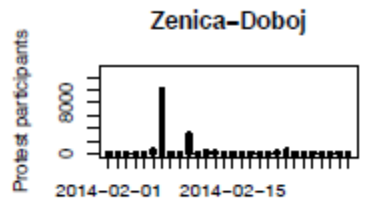

Date

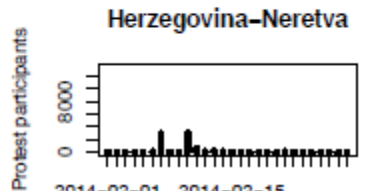

Date

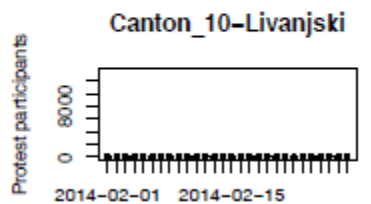

Date

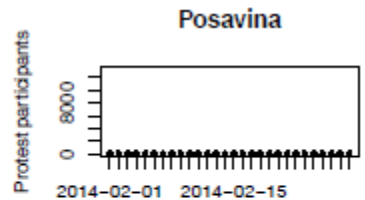

Date

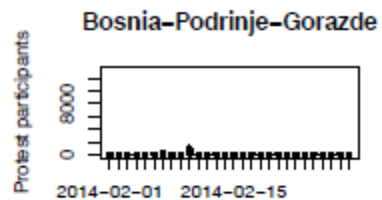

Date

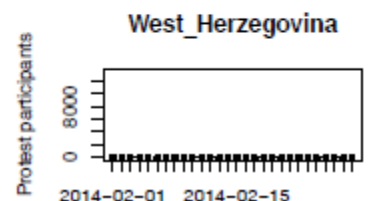

Date

Figure 3: Estimated participants by $\mathrm{FBiH}$ canton and the RS 


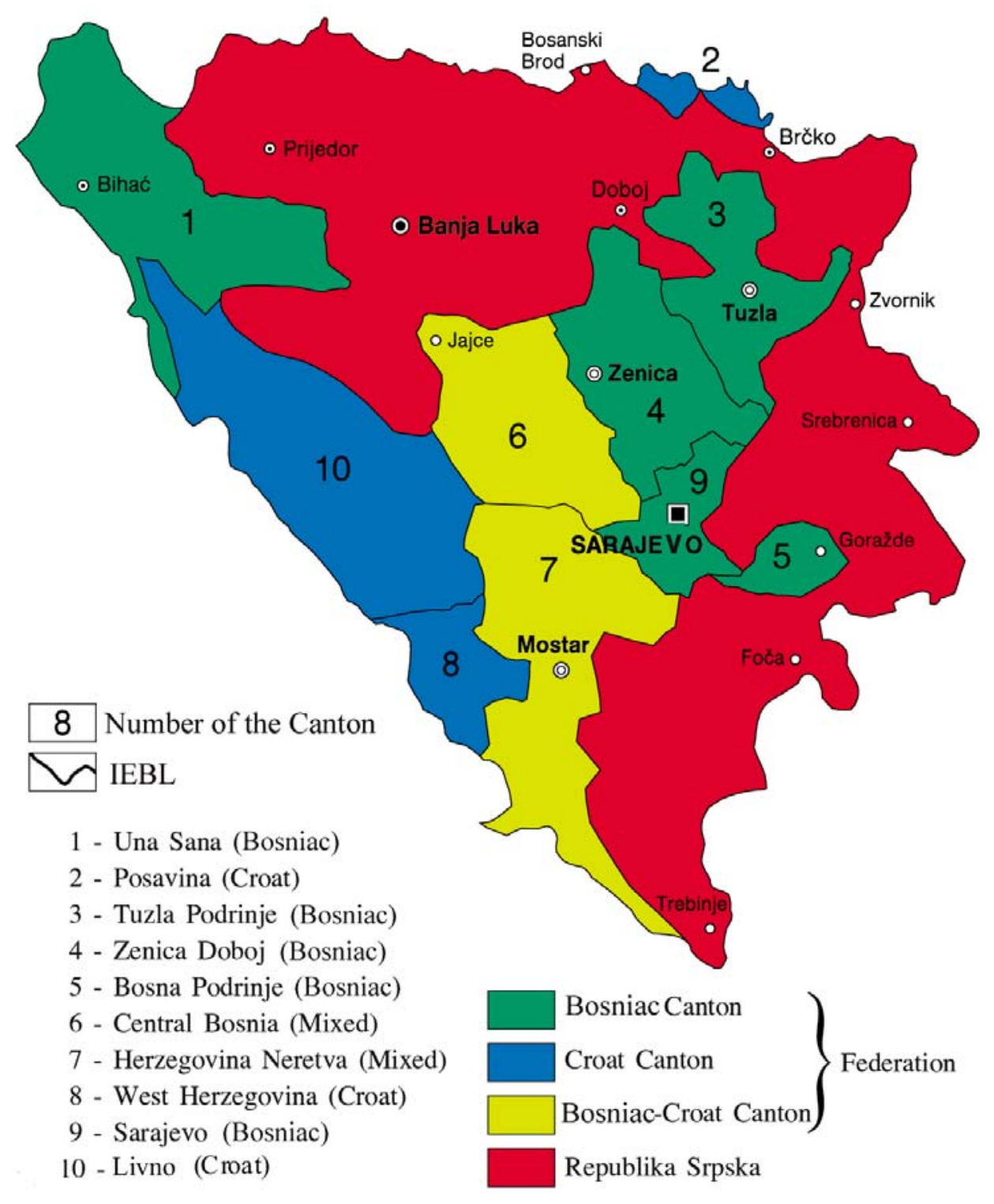

Figure 4: Cantons of $\mathrm{FBiH}$ and the RS (source: http://asusilc.net/scr101/les1/bosna1.jpg).

In our analyses below we treat government responses from each jurisdiction as a single unit, i.e., the $\mathrm{FBiH}$ and $\mathrm{RS}$ respectively. Note that beyond the separation between the two governments or jurisdictions, Bosnia and Herzegovina is not a federal unit and the local regions/cantons have limited autonomy or repressive power. Hence, there is little basis for trying to examine variations across regions based on 
differences in responses from local authorities, and we believe that individuals primarily responded to what they see as the central government. In line with our argument, the complex composition of the government also implies that inconsistency can arise as a result of the actions of different individuals rather than changes in the position of a unified executive per se. ${ }^{9}$

Whereas public displays of grievances such as strikes and demonstrations dominated during the month of February, efforts to organize indoor assembly meetings called "plenums" become more common in the following months. In our data we do not code these plenums as protest events. They do not constitute public challenges through direct action, given the indoor nature of the event. Moreover, the lack of news coverage makes it more difficult to adequately track the number of plenum participants. Finally, the move from street protest to these popular assemblies, held to be "open to all citizens", in our view illustrate the regularization of dissent after the peak of protest mobilization towards conventional political action, which contrasts with the more spontaneous nature of the initial protest wave. These assemblies were formed primarily to let participants formulate in a more structured way claims against state institutions and political leaders as the initial irregular protest momentum was fading away (De Noni 2014).

Our database also contains information on the mode of actions that protesters engaged in (i.e., whether clearly nonviolent or violent), the specific tactics used in the event (e.g., occupation, demonstration), the location where the event took place, recording the specific cities/towns as well as the canton and/or entity, and finally the

\footnotetext{
9 See https://www.theguardian.com/news/datablog/2014/oct/08/bosnia-herzegovinaelections-the-worlds-most-complicated-system-of-government.
} 
government responses observed in the aftermath of the event and whether this was repressive or accommodative. We also identify the institutional source of repressive and accommodative behaviors, i.e. government at the municipal, cantonal, entity or national level. Our data also identify various types of contentious collective action (threatening authorities with protests, direct democratic action, confrontational action, violent action, decision/call to stop protest action, pro-government protest action), with several sublevels used to determine the particular action type (see Appendix 2). Similarly, the variables coding government response - GOVERNMENT_repression and GOVERNMENT_concession - have several different indicators. Both, GOVERNMENT_repression and GOVERNMENT_concession are coded as categorical, ordinal variables where a value of 2 represents high levels of repression and concession respectively, 1-low levels, 0-no repression/no concession (see Appendix 2 for full details).

To code inconsistency in government responses and test its impact on subsequent protests events, we examined whether we see repression, concessions, or a mixture of both during the same day or period. In our raw data, the variable GOVERNMENT inconsistency takes a value of 0 if the response is consistent and the government uses only repression or only concession during a particular day, or neither, and the variable is assigned a value of 1 indicating inconsistency if the government used both repression and concession on the same day. In our analyses below we generally aggregate the coding of inconsistency for combinations of concessions and repressions over longer windows of several days. We also combine high and low repression in the analyses. given the small number of available data points to conduct separate analyses to distinguish variation in the relative balance or degree of mixes towards more or less repressive and accommodative inconsistent 
responses. Figure 5 displays the distribution of government responses at the daily level. As can be see, the modal category is no direct response, but clear concessions are more common than repression only for cases where we observe a direct response.

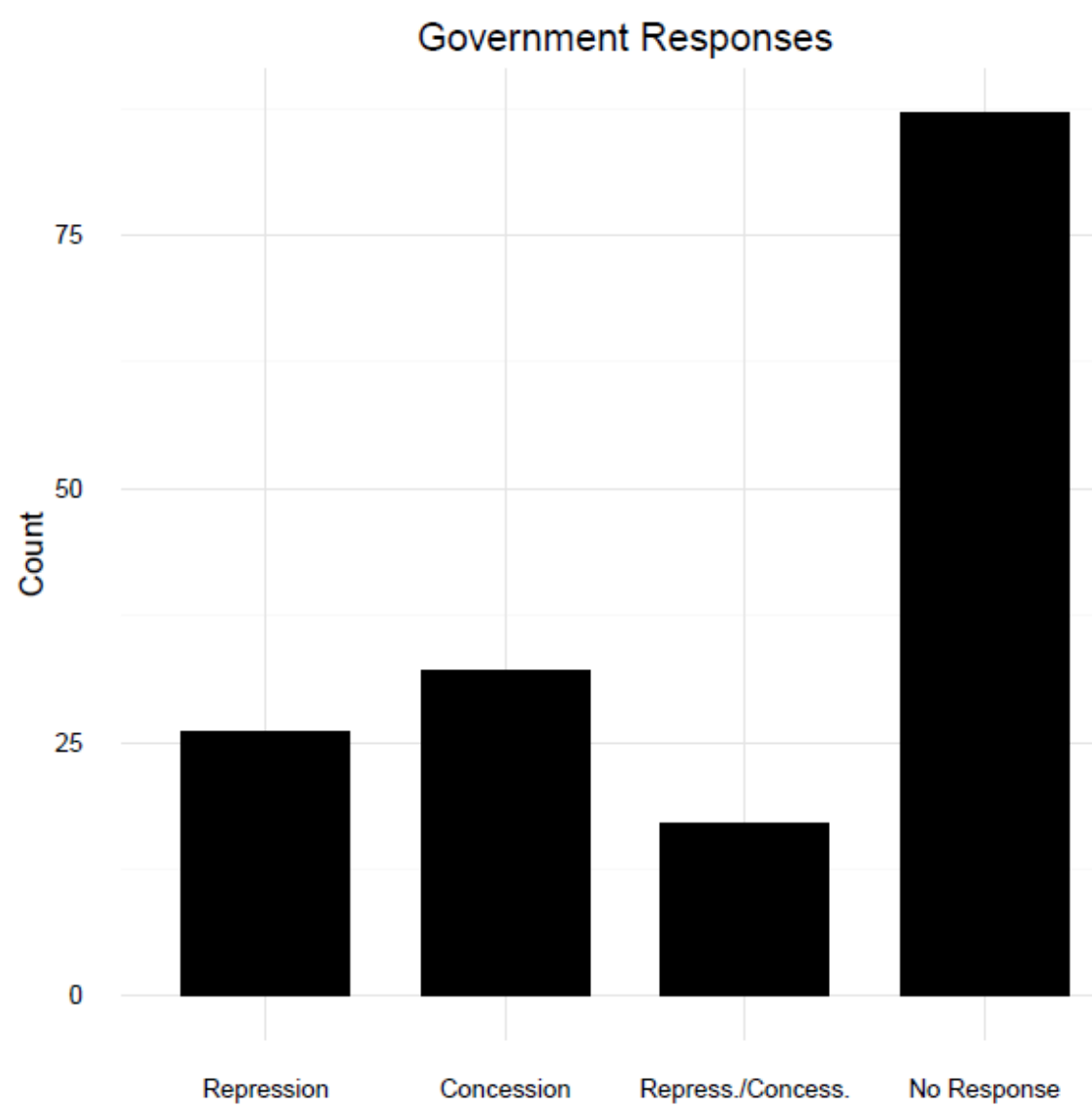

Figure 5: Distribution of government responses to protest.

While concessions are somewhat more common overall, we see a clear differentiation between the two administrative units of $\mathrm{BiH}$. The RS government has mainly responded to protest activities by discrediting participants in $\mathrm{FBiH}$ and actively ignoring protests in the RS. By contrast, the $\mathrm{FBiH}$ government has used highly repressive tactics, such as beatings, imprisonment and terrorist charges for the protesters that allegedly participated in burning of the government buildings in 
Sarajevo, but also used a wide range of accommodative tactics ranging from the release of political prisoners, reshuffling of administrative personnel, resignations, investigations into corrupt officials, meeting with protesters to hear their demands, announcing social reforms and legal measures, and changing electoral laws among many others.

\section{Empirical Analysis}

We have argued that differences in government responses and their impact on individual expectations can help account for the differences in the protest mobilization trends between the RS and $\mathrm{FBiH}$. This claim is difficult to test explicitly in the case of RS, because it relies on a counterfactual, or something that we do not observe. In other words, we observe only repression and no accommodation to protests in the RS, and hence no inconsistent behavior that could have motivated people to increase participation in protest. However, we can evaluate the implications of the argument by looking at variation over time in protests in the FBiH. Figure 6 shows the daily number of protest participants in the $\mathrm{FBiH}$. If our argument is correct, then participation should evolve as a reaction to government responses. 


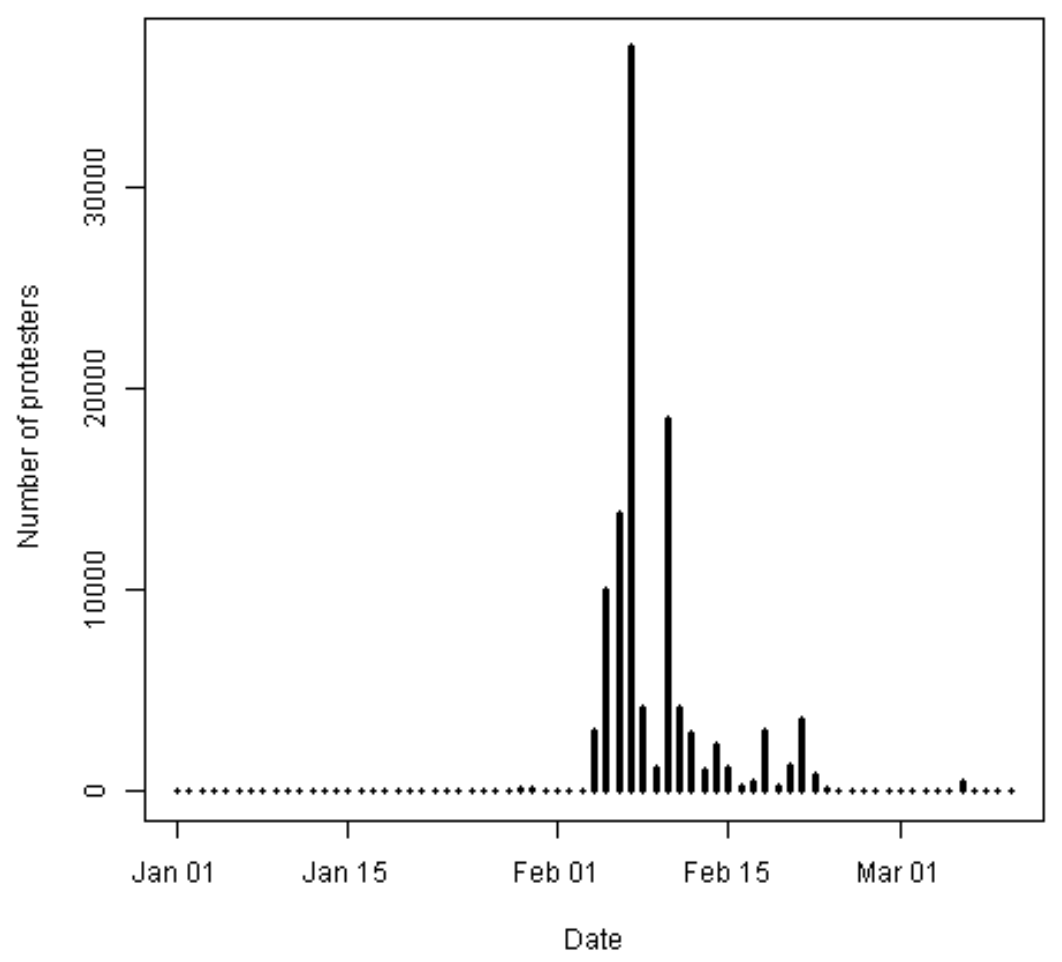

Figure 6: Daily number of protest participants in $\mathrm{FBiH}$.

To evaluate this, we use the raw data described above to create a daily data set of all events and the recorded number of protests in all of the FBiH. We only examine the aggregate number of participants here, since most of the government responses are not specific to particular cantons. Our data contain a number of very small protest events, but most protesters participated in a few very large events, which seem qualitatively different. We believe that the number of protestors provide the most appropriate test for our argument on mobilization escalation. When events are highly aggregated, the correlation between total participation and event frequency is generally low or modest, and the findings from one measure do not generally extend to the other measure (see Biggs 2016). However, we also provide robustness tests with the number of protest events, which potentially may better reflect growth in the 
geographical scope of mobilization. Figure 7 shows the distribution of distinct protest events by day for the FBiH. Although the first peak coincides for events and participants, the number of events per se cannot distinguish between the events with limited and very high participation.

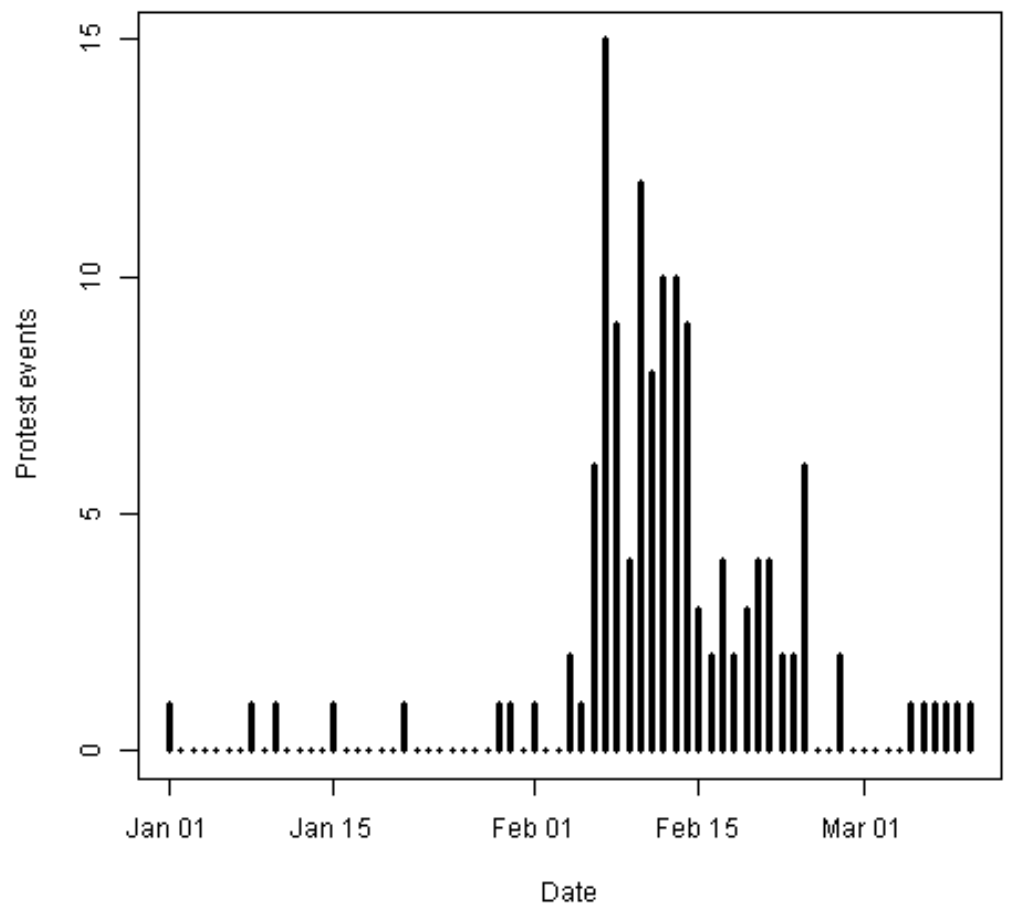

Figure 7: Daily number of protest events in the FBiH.

To examine inconsistency in government responses we look at the prior three days, and we code government responses as inconsistent if we see both repressive and accommodative responses over the period. The logic of looking at the prior three days is that we expect the expectations to enter with some lag. In order to know about an event, individuals would need to see reports (which typically emerge the following day) and then prepare for participation. A window of three days should be sufficient to capture the impact of inconsistency on participation. 
To evaluate our claim we first conduct a series of regressions with the logged number of daily protests in Table 1 . We use the logged number of participants, since the number of participants is measured in thousands for many days, We use OLS rather than a count model, since the latter typically is better suited for moderate counts. As can be seen, we find a large positive coefficient in Model 1 in Table 1, indicating higher participation following inconsistent behavior, consistent with our claim that inconsistent behavior served to both highlight existing grievances as well as changing expectations about the opportunities for concessions in $\mathrm{FBiH}$.

Model 2 in Table 1 adds a time trend to the model in order to consider whether the inconsistent behavior may simply reflect some secular trend where the government responses became more erratic over time. As can be seen, we find no simple linear trend in these data, and our estimate of inconsistency is not affected. Finally, to ensure that increased participation does not reflect accurate expectations about repression and accommodation we add a term indicating whether events ultimately are repressed or accommodated. As can be seen, both of these terms are positive, indicating a possible endogenous relationship where events with higher participation are more likely to receive a response from the government. However, they do not change the sign or significance for past inconsistency, thus indicating that our results cannot be dismissed as an artifact of future expectations. 


\begin{tabular}{|c|c|c|c|}
\hline & \multicolumn{3}{|c|}{ Dependent variable: } \\
\hline & \multicolumn{3}{|c|}{ Log protesters } \\
\hline & (1) & (2) & (3) \\
\hline Government inconsistency (past) & $\begin{array}{l}4.177^{* * *} \\
(0.706)\end{array}$ & $\begin{array}{c}4.140^{* * *} \\
(0.837)\end{array}$ & $\begin{array}{l}3.119^{* * *} \\
(0.762)\end{array}$ \\
\hline Time & & $\begin{array}{c}0.002 \\
(0.021)\end{array}$ & $\begin{array}{l}-0.013 \\
(0.019)\end{array}$ \\
\hline Repression (current) & & & $\begin{array}{l}2.393^{* * *} \\
(0.860)\end{array}$ \\
\hline Concessions (current) & & & $\begin{array}{l}2.091^{* *} \\
(0.916)\end{array}$ \\
\hline Constant & $\begin{array}{c}0.550 \\
(0.481)\end{array}$ & $\begin{array}{c}0.506 \\
(0.718)\end{array}$ & $\begin{array}{c}0.330 \\
(0.618)\end{array}$ \\
\hline Observations & 69 & 69 & 69 \\
\hline $\mathrm{R}^{2}$ & 0.343 & 0.343 & 0.542 \\
\hline Adjusted $\mathrm{R}^{2}$ & 0.333 & 0.323 & 0.513 \\
\hline Residual Std. Error & $2.926(\mathrm{df}=67)$ & $2.948(\mathrm{df}=66)$ & $2.500(\mathrm{df}=64)$ \\
\hline F Statistic & $35.0^{* * *}(1 ; 67)$ & $17.2^{* * *}(2 ; 66)$ & $18.9^{* * *}(4 ; 64)$ \\
\hline
\end{tabular}

Table 2 repeats the previous analysis with the number of events rather than protestors. The results are similar in quantitative sense, although the effects are more muted, possibly as a result of counting locations rather than the scaled magnitude of events. Using shorter/longer windows of one/five days for inconsistency yield qualitative similar results. Alternative estimates using a negative binomial model of the number of events also yield substantively similar results. Hence, we conclude that our argument seems supported by the variation over events and over time, regardless of whether we look at the number of protesters or the number of events. 


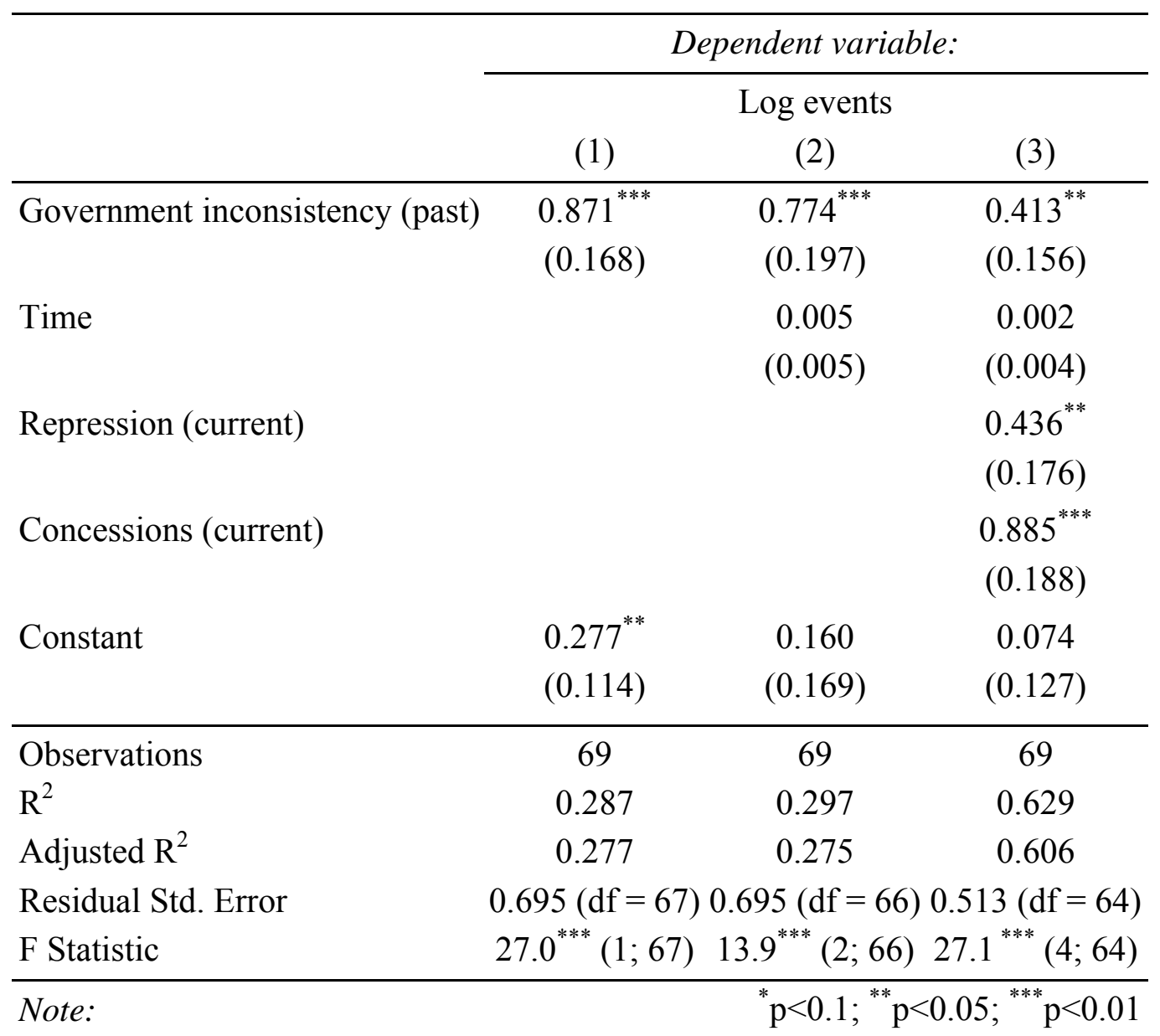

\section{Discussion and conclusion}

The protests in $\mathrm{BiH}$ in 2014 are interesting for a number of reasons. First, they illustrate that economic marginalization and poor governance can create common grievances and mobilization, even in deeply ethnically divided societies with pervasive mistrust (see Alesina and LaFerrara 2002). The 2014 wave of antigovernment protests indicates that common cross-ethnic social problems and political ineffectiveness actually can unite individuals across ethnic lines, even if Serbs participated to a lesser extent as the protest did not grow to the same extent in the RS as in the $\mathrm{FBiH}$. 
Second, we believe that the special case of an administratively divided state with similar political and economic conditions in the two units, i.e., the $\mathrm{FBiH}$ and $\mathrm{RS}$, provides an interesting laboratory for studying variation in government responses and the effects on mobilization. Despite similar initial economic conditions, the FBiH saw major contentious collective action, while the unrest did not extend to the RS. We have argued that that the consistent repressive tactics by the RS government and inconsistent responses by the $\mathrm{FBiH}$ account for the differences in mobilization across the two entities. Our findings are in line with Lichbach's (1987) model that suggests that consistent government responses, whether repressive or accommodative actions, can reduce dissent, while inconsistent government responses seem to signal to people that change is possible, and may increase individual willingness to participate and join others in dissent (see also Klandermans 1984). Our highly disaggregated database on the 2014 protest in $\mathrm{BiH}$ allow for a more direct test of these argument on how collective action is shaped by government responses.

With regards to policy implications, our results could be interpreted in a very negative sense as providing support for the effectiveness of preemptive repressive tactics used in the RS, and the perils of combining attempts to contain protest with efforts to provide at least some recognition of the concerns of the protesters. While we may deplore these implications from a perspective emphasizing justice or reform, it is hard to deny that perceived repression often can be effective and deter dissent. This, however, does not mean that dissent can never yield political change or that all efforts to mobilize over grievances are necessarily futile. All societies have vulnerabilities, and organized dissident, with large numbers of potential supporters with common grievances can find them (see Chenoweth and Stepan 2011). The mobilization against Milosević in Serbia had to go through a series of failures before finally achieving 
success (see Popović 2014). Thus, the protest events should serve as a signal to the politicians the national level in $\mathrm{BiH}$ and both entities that the plight of people should not be ignored, and that protest can arise even when the odds are against and take a government by surprise. 


\section{Bibliography}

Alesina, Alberto, and Eliana La Ferrara. 2005. Ethnic Diversity and Economic Performance. Journal of Economic Literature 43:721-761.

Alesina, Alberto and Eliana La Ferrara. 2002. Who Trusts Others? Journal of Public Economics 85: 207-234.

Andrews, Kenneth T. and Michael Biggs. 2006. The Dynamics of Protest Diffusion: Movement Organizations, Social Networks, and News Media in the 1960 SitIns. American Sociological Review 71: 752-777

Arsenijević, Damir (Ed). 2014. Unbribable Bosnia and Herzegovina. Baden-Baden: Nomos.

Beber, Florian. 2014. Is Change Coming (Finally)? Thoughts on the Bosnian Protests. Available at https://florianbieber.org/2014/02/09/is-change-coming-finallythoughts-on-the-bosnian-protests/.

Beber, Florian. 2006. Post-War Bosnia: Ethnic Structure, Inequality and Governance of the Public Sector. London: Palgrave.

Bhprotestfiles. 2014. Konjuh Workers Fined for Civil Disobedience. 18 February, (video with subtitles), https://bhprotestfiles.wordpress.com/2014/02/18/konjuhworkers-fined-for-civil-disobedience/.

Biggs, Michael. 2016. Size Matters: Quantifying Protest by Counting Participants. Sociological Methods and Research 45(3): 1-33.

Bosnia and Herzegovina Today. 2014. International Overseers might Send EU Troops to Bosnia if Social Unrest Escalates - Inzko. IntelliNews, February 10

Busuladžić, Emina. 2014. Why? In Damir Arsenijević.(Ed). Unbribable Bosnia and Herzegovina. Baden-Baden: Nomos. 
Cederman, Lars-Erik; Kristian Skrede Gleditsch \& Julian Wucherpfennig. 2017.

Predicting the Decline of Ethnic Conflict: Was Gurr Right, and for the Right

Reasons? Journal of Peace Research, forthcoming.

Cederman, Lars-Erik, Simon Hug, Andreas Schädel, and Julian Wucherpfennig. 2015.

Territorial Autonomy in the Shadow of Conflict: Too Little, Too Late?

American Political Science Review 109 (2): 354-70.

Chenoweth, Erica, and Maria. J. Stephan. 2011. Why Civil Resistance Works: The

Strategic Logic of Nonviolent Conflicts. New York: Columbia University Press.

Chenoweth, Erica, and Maria J. Stephan. 2008. Why Civil Resistance Works: The Strategic Logic of Non-violent Conflict. International Security 33(1): 7-44

Ceriani, Lidia, and Caterina Ruggeri Laderchi. 2015. Poverty and Social Exclusion in Bosnia and Herzegovina: Insights from the 2011 Extended Household Budget Survey. Washington, DC: World Bank, available at http://tinyurl.com/gwd4oty.

Cihan News Agency. 2014. Bosnia Anti-government Protests Enter Sixth Day Amid Unrest, 11 February.

Cunningham, Kathleen. 2011. Divide and Conquer or Divide and Concede: How Do States Respond to Internally Divided Separatists? American Political Science Review 105(2): 275-297.

Cunningham, Kathleen and Emily Beaulieu. 2010. Dissidents, Repression, and Inconsistency". In Erica Chenoweth and Adria Laurence (eds.). Rethinking Violence: State and Nonstate Actors in Conflict. Cambridge, MA: MIT Press, 173-198.

Davenport, Christian. 2007. State Repression and Political Order. Annual Review of Political Science 10: 1-23. 
Dahl, Marianne; Scott Gates, Kristian Skrede Gleditsch, and Belén González. 2016. Accounting for Numbers: How Actor Profiles Shape the Choice of Violent and Non-violent Tactics. Typescript, Peace Research Institute cOslo.

Downes, Alexander B. 2008. Targeting Civilians in War. Cornell University Press.

De Noni, Andrea. 2014. Bosnia and Herzegovina: The Plenum Legacy. Osservatorio Balcani e Caucaso. Transeuropa, 9 August, available at http://www.balcanicaucaso.org/eng/Areas/Bosnia-Herzegovina/Bosnia-andHerzegovina-the-Plenums-legacy-155351.

DL.O. 2014.Opravdano Nezadovoljstvo. [Justified Dissatisfaction]. Oslobodjenje. 8 February. http://www.infobiro.ba/article/863497.

E.S., 2014.Radnici TTU: Gladni smo na tri jezika. [Workers in TTU (Transport Appliance Factory): We are Hungry in Three Languages]. Nezavisne Novine. 3 April. http://www.nezavisne.com/ekonomija/privreda/Radnici-TTU-Gladnismo-na-tri-jezika/297837.

Feather, Norman. 1982 Expectations and Actions: Expectancy-Value Models in Psychology. Hillsdale, NJ: Erlbaum.

Francisco, Ronald A. 1995. After the Massacre: Mobilization in the Wake of Harsh Repression. Mobilization: An International Journal 9 (2) 107-126.

Fischer, Martina. 2006. Civil Society in Conflict Transformation: Ambivalence, Potentials and Challenges. Berlin: Berghof Research Center for Constructive Conflict Management.

Gamson, William. A. 1975. The Strategy of Social Protest. Homewood, IL: Dorsey Press 
Gamson, William A. Gamson, David Croteau, William Hoynes, and Theodore Sasson. 1992. Media Images and the Social Construction of Reality. Annual Review of Sociology 18: 373-393

Granovetter, Mark. 1978. Threshold Models of Collective Behavior. American Journal of Sociology 83:1420-43.

Gurr, Ted. R. 1970. Why Men Rebel. Princeton, NJ: Princeton University Press.

Haber Ba.2014. Bez incidenta - Mirni protesti u Bijeljini. [Without incident: Peaceful protests in Bijeljina]. 9 February.

International Crisis Group. 2014. Bosnia’s Future. Europe Report №232, July 2014. http://www.crisisgroup.org/ /media/Files/europe/balkans/bosniaherzegovina/232-bosnia-s-future.pdf.

IntelliNews. 2014. Bosnia and Herzegovina Today: International Overseers might Send EU Troops to Bosnia if Social Unrest Escalates, 10 February.

Jenkins, J. Craig and Charles Perrow. 1977. Insurgency of the Powerless: Farm Workers Movements. Annual Review of Sociology 42: 249-68

Jukić, Elvira. 2014. Dodik: Cilj protesta destabilizacija RS. [The Aim of the Protests is the Destabilization of the RS]. Balkan Insight.28 February., http://www.balkaninsight.com/en/article/dodik-cilj-protesta-destabilizacijars/1431/45.

Kerpelman, Larry C. 1969. Student Political Activism and Ideology: Comparative Characteristics of Activists and Nonactivists. Journal of Counseling Psychology $16(1): 8-13$.

Khawaja, Marwan. 1993. Repression and Popular Collective Action: Evidence from the West Bank. Sociological Forum 8:47-71. 
Klandermans, Bert. 1984. Mobilization and Participation: Social-psychological Expansions of Resource Mobilization Theory. American Sociological Review 49(5): 583-600.

Kaufman, Stanley. 1989. Review of A Dry White Season (film), directed by Euzhan Palcy. The New Republic, 9 October, pp. 24-25.

Klix. 2014. Vecina gradana podrzava proteste, a nasilije predstavlia cijenu promjena [The majority of citizens support the protests, and the violence is a necessary price for change to happen], 12 February, available at http://balkanist.net/protests-in-bosnia-and-herzegovina-live-blogs-and-updates.

Kocher, Matthew A., Thomas Pepinsky, and Stathis N. Kalyvas. 2011. Aerial Bombing and Counterinsurgency in the Vietnam War. American Journal of Political Science 55 (2) 201-218.

Kostić, Roland. 2007. Ambivalent Peace: External Peacebuilding Threatened Identity and Reconciliation in Bosnia and Herzegovina. PhD Dissertation, Department of Peace and Conflict Research, University of Uppsala.

Labour Force Survey (2014). Labour Force Survey, Final Results. Agency for Statistics of Bosnia and Herzegovina, available at http://www.bhas.ba/ankete/LFS_2014_001_01_bh.pdf

Landsberger, Henry A. 1976. Labor movements, social movements and social mobility. In Robert Dubin (ed.) Handbook of Work Organization and Society. Chicago: Rand McNally, pp. 837-877.

Le Bon, Gustave. 1896. The Crowd. London: Unwin.

Lichbach, Mark I. 1995. The Rebel's Dilemma. Ann Arbor, MI: University of Michigan Press. 
Lichbach, Mark I. 1987. Deterrence or Escalation? The Puzzle of Aggregate Studies of Repression and Dissent. Journal of Conflict Resolution, 31(2) 266-297.

Marzal, Andrew 2014. Bosnia Protests: 150 injured as demonstrators set fire to presidential palace. Protesters across Bosnia set fire to government buildings and fight with riot police amid protesters over unemployment and corruption. The Telegraph, February 8. Accesses July 25, 2016 http://www.telegraph.co.uk/news/worldnews/europe/bosnia/10625810/Bosniaprotests-150-injured-as-demonstrators-set-fire-to-presidential-palace.html.

Marx, Gary T. and Wood, James L. 1975. Strands of Theory and Research in Collective Behavior. Annual Review of Sociology 1: 363-428

McAdam, Douglas. 2003. Beyond Structural Analysis: Towards a More Dynamic Understanding of Social Movements. In Mario Diani and Doug McAdam (eds.) Social Movements and Networks: Relational Approaches to Collective Action. Oxford: Oxford University Press, pp. 281-298.

McCarthy, John .D. and Mayer N. Zald. 1977. Resource Mobilization and Social Movements: A Partial Theory. American Journal of Sociology. 82: 1212-1241

Milan, Chiara. 2014. New Social Movements Arise in Bosnia-Herzegovina. ROARmag, 18 December.

Muhelmann, Thomas. 2008. Police Restructuring in Bosnia-Herzegovina: Problems of Internationally-led Security Sector. Journal of Intervention and StateBuilding, 2(1): 1-22.

Mujanovic, Jasmin and Heather McRobie. 2014. The Evolution of Bosnia's Protest Movement. https://www.opendemocracy.net/5050/jasmin-mujanovi\%C4\%87heather-mcrobie/evolution-of-bosnia $\%$ E2\%80\%99s-protest-movementinterview-with-jasmin-m. 
Muller, Edward. N. and Erich Weede. 1990. Cross-National Variation in Political Violence: A Rational Action Approach. Journal of Conflict Resolution 34:624651.

Oberschall, Anthony. 1973. Social Conflict and Social Movements. Englewood Cliffs, NJ: Prentice-Hall.

Olivier, Johan L. 1991. State Repression and Collective Action in South Africa, 19701984. South African Journal of Sociology 22: 109-17.

Olson, Mancur. 1965. The Logic of Collective Action: Public Goods and the Theory of Groups. Cambridge, MA: Harvard University Press.

Piazza, James A., and James. I. Walsh. 2010. Physical Integrity Rights and Terrorism. PS: Political Science and Politics 43(3): 411-414.

Popović, Srdja M. 2014. Blueprint for Revolution: How to Use Rice Pudding, Lego Men, and Other Nonviolent Techniques to Galvanize Communities, Overthrow Dictators, or Simply Change the World. London: Penguin.

Pugh, Michael. 2005. Transformation in the Political Economy of Bosnia since Dayton. International Peacekeeping 12(3): 448-462.

Radio Sarajevo. 2014.Strajkovi, demonstracije, blokade: Interaktivna hronologija gradjanskog bunta in $\mathrm{BiH}$. [Strikes, demonstrations, blockades : Interactive chronology of civil rebellion and $\mathrm{BiH}]$. http://www.radiosarajevo.ba/mobile/novost/158005.

Rasler, Karen. 1996. Concession, Repression, and Political Protest in the Iranian Revolution. American Sociological Review 61(1): 132-152.

Sadiković, Adis. 2014. February Stirrings. In Damir Arsenijevic (Ed). Unbribable Bosnia and Herzegovina. Baden-Baden: Nomos. 
Sladojević, Dragan and Miro Lingo-Demirović, M. 2014. Dugogodišnja robija za paljenje i rušenje. [A long-term jail sentence for arson and demolition of public property.] Nezavisne Novine. Published 14 February, available at http://www.infobiro.ba/article/864046.

Snow, David A., Louis A. Zurcher and Sheldon Ekland. 1980. Social Networks and Social Movement: A Microstructural Approach to Differential Recruitment. American Sociological Review 45(5): 787-801

Šunj, Nermina. 2014. Ono Sto Izaziva Bunt: 10 najvecih privatizacijskih pljacki u Bosni I Hercegovini [The Root Cause of the Rebellion: Top Ten Privatization Plunders in Bosnia and Herzegovina]. Žurnal. 9 February. https://bhprotestfiles.wordpress.com/2014/03/10/the-root-cause-of-therebellion-top-ten-privatisation-plunders-in-bh/.

Tarrow, Sidney. 1994. Power in Movement. Cambridge and New York: Cambridge University Press.

Thomas, Jakana L. 2014. Rewarding Bad Behavior: How Governments Respond to Terrorism in Civil War. American Journal of Political Science 58(4): 804-818.

.Tilly, Charles. 1978. From Mobilization to Revolution. Reading, MA: AddisonWesley.

Tilly, Charles and Sidney Tarrow. 2007. Contentious Politics. Boulder, CO: Paradigm Publishers.

Williams, Rhodri C., 2004. Post-Conflict Property Restitution and Refugee Return in Bosnia and Herzegovina: Implication for International Standard Settings and Practice. Journal of International Law and Politics 37 (1): 441-553. 


\section{Appendix 1: Search keywords}

protest mutiny rebellion strike strikes tear gas spring riots rock protesters demonstrators demobilized soldier unemployed unemployment aggrieved privatization burning plenum assemblies resignation corruption religious leaders of the Interreligious Council Inter-religious Council Radmanovic Izetbegovic KomsicDodikRadmanovicCovic Izetbegovic KomsicDodikFincija Ceric Puljic Finns Ceric Puljic Bishop Metropolitan Presidency Incko

Table A1. Total Number of published articles by publication for local sources

\begin{tabular}{|c|c|c|c|c|}
\hline & January & February & March & April \\
\hline Oslobodjenje & 528 & 573 & 564 & 587 \\
\hline DnevniAvaz & 498 & 495 & 616 & 564 \\
\hline Dnevni List & 327 & 317 & 357 & 357 \\
\hline NezavisneNovine & 283 & 289 & 313 & 304 \\
\hline
\end{tabular}


Appendix 2: Data structure example, with variables and values

Table B1: Data structure example

\begin{tabular}{|c|c|c|c|c|c|c|c|c|}
\hline $\begin{array}{c}\text { Protest } \\
\text { _City/Town }\end{array}$ & CantonID & Entity & Date & $\begin{array}{l}\text { Protest } \\
\text { _Action }\end{array}$ & Gov.Lev. & Gov.Rep & Gov.Con & $\begin{array}{c}\mathbf{N} \\
\text { _protesters }\end{array}$ \\
\hline Tuzla & 3 & FBIH & 2014-02-06 & violent & $\begin{array}{l}\text { cantonal; } \\
\text { entity }\end{array}$ & 2 & 2 & 6000 \\
\hline Tuzla & 3 & FBIH & 2014-02-07 & violent & $\begin{array}{c}\text { local; } \\
\text { cantonal }\end{array}$ & 2 & 1 & 10000 \\
\hline Sarajevo & 9 & FBIH & 2014-02-09 & nonviolent & entity & 2 & 1 & 1000 \\
\hline Sarajevo & 9 & FBIH & 2014-02-10 & nonviolent & entity & 0 & 2 & 5000 \\
\hline Banja Luka & 0 & RS & 2014-02-07 & nonviolent & none & 0 & 0 & 300 \\
\hline Banja Luka & 0 & RS & 2014-02-08 & nonviolent & none & 0 & 0 & 300 \\
\hline Banja Luka & 0 & RS & 2014-02-09 & no protests & entity & 1 & 0 & 0 \\
\hline
\end{tabular}


Table B2. GOVERNMENT_repression values

0. None

- No attempt to repress

\section{Low-level repression}

- Block/deviate marches

- Discredit (public speeches, interviews, statements, explicitly saying that they do not want to give up their positions)

- Threats

- Investigations into activists (personal and public activities)

- Refusing to meet demands

\section{High-levels repression}

- Physical, non-lethal intervention/violations of physical integrity rights (beatings, police raids, throwing tear gas)

- Banning Protests

- Restricting individual's civil rights (right to fair trial)

- Imprisonment (imprisonment as a consequence of activism)

NA- missing data (no available information) 
Table B3. GOVERNMENT_concession values

0. None

- No attempts to concede

\section{Low-level concession}

- Symbolic actions of conceding (ex. of security forces deciding to put down their armour, take off their protective gear).

- Admitting that the situation in the country is difficultsympathizing with protesters

- Release of political prisoners

- Pardons/amnesties

- Reshuffling of administrative personnel

- Arrest of controversial government figures (Investigations into corrupt and illegal activities by the government officials)

- Addressing protesters in the public squares, on the streets

- Offering to reduce salaries of political officials

- Recognizing people right to protests

2. High-level concession, expressing willingness to accommodate the demands:

- Call upon parliamentary debate on the protesters' demands

- Meeting of political leaders, religious leaders and elites to find a common ground

- Appointment of government figures advocating for social justice and equality

- Announcement of social reforms and legal measures (regardless of the implementation, ex. in domestic sources- D2 Nezavisne Novine 2014-02-01)

- Changing the electoral law to have early elections to address protester demands

NA. missing data (no available information) 
Table b4, PROTESTER_action_type values

1. Threatening authorities with mass protests

2. Direct democratic actions (legal)

- demanding referendum/early elections

- collecting signatures/petitioning/sending letters of protest

- mass meetings (plenums)

- attending meetings of cantonal/city assemblies

3. Confrontational protest actions

- Boycotts

- Strikes

- Defying bans on demonstrations and gatherings

- Blockades of streets and public spaces

- Self-mutilation/hunger-strike

- Vigils/picketing/other symbolic acts ()

- Demanding a release of imprisoned activists

- Demanding resignation of government officials

4. Violent protest actions

- Burning/damaging state insignia

- Damaging public property (throwing stones, paint, breaking windows)

- Threats of bombing state property

- Physical fights with security forces

- Physical fights with civilians

- Sabotage (electronic/cyber attacks)

- Damaging private property

- Clashes with police

- Detaining government officials

5. Decision to stop protest activities

- Protester leaders/representatives calling off protest activities saying that their demands were met

6. Pro-government protests

NA. Missing data (no available information) 